\section{The Scenery of New Zealand}

NEw ZEaLAND has long been careful of State protection of natural features of outstanding value on the grounds both of scientific interest and of scenic beauty. The Annual Report on Scenery Preservation for the year ending March 31, 1935, records additional reserves of 2,027 acres, making a present total of 671,000 acres in 965 reserves. Many of the reserves aim at preserving areas of characteristic vegetation, and it is to be noted that the Native Plants Protection Act came into foree in 1935. By this Act, all native plants, except a few species commonly regarded as weeds, are protected throughout the Dominion. There are, however, provisions for taking plants in reasonable numbers for scientific study or medicinal purposes. The larger reserves seem to have paid wardens, but many of the smaller ones are cared for by honorary inspectors.

\section{Announcements}

THE Brazilian Government has recently founded an international centre for the study of leprosy at Rio de Janeiro.

ThE fifteenth Japanese Congress of Physiology will be held next August at the Ohara Institute of Kurashihi, Oyama, and will last three days.

ThE International Federation of Eugenic Societies will hold a congress on July 16-21 at Scheveningen and The Hague. Further information can be obtained from the vice-president, Dr. Georges Schreiber, Avenue du Recteur Poincaré 26, Paris XVIe.

THE Institute for Investigation of the Brain, at Leningrad, which contains 180 cerebral hemispheres of adults, 300 of children and $\mathbf{4 7 0}$ of lower animals, is engaged in the preparation of a microscopical atlas of the cerebral hemispheres of man and the lower animals. It is also occupied with the study of the brains of the most eminent representatives of science, art and politics.

THE first International Conference on Fever Therapy will be held at Columbia University, New York City on September 29-October 3, its aim being to collect and crystallise data connected with fever induced by physical or other agencies as a therapeutic procedure. The subscription is $\mathbf{1 5}$ dollars. Further information can be obtained from the secretary, Dr. William Bierman, 471 Park Avenue, New York City.

Dr. Hellmut de Terra informs us that a mistake has been made in the first column of the table accompanying his article "Late Cenozoic History in India" in Nature of April 25, p. 686. The Upper Pleistocene period covers the stages of column 2 named Redeposited silt, Erosion and Potwar; the Middle Pleistocene covers the stages named Erosion and Boulder Conglomerate; the Lower Pleistocene covers the stages named Pinjaur and Tatrot. The broken line indicating an unconformity which appears between the Boulder Conglomerate and the Pinjaur should extend across the column to the left between "Middle" and "Lower".
ApPlications are invited for the following appointments, on or before the dates mentioned :

A teacher of electrical engineering in the Newton Heath Branch Technical School-The Director of Education, Education Offices, Deansgate, Manchester, 3 (June 15).

A teacher of chemistry and mathematics in the North-Western Polytechnic, Prince of Wales Road, Kentish Town, London, N.W.5-The Secretary (June 17).

A teacher of mechanical engineering in the Rugby College of Technology and Arts-The Principal and Organizer of Further Education in Rugby, 61 Clifton Road, Rugby (June 18).

A lecturer in charge of the Department of Civil Engineering in the University of Sheffield-The Registrar (June 18).

A lecturer in biochemistry and a lecturer in physiology in the University of Leeds-The Registrar (June 19).

A scientific officer (A.4) for research in chemical problems, a scientific officer $(A .40)$ for research in strength of aircraft structures and materials, an assistant (Grade I, A.48) for research in aeronautical electrical equipment, and assistants (Grade III, A.58/83) for tests in the Aerodynamics Department, of the Air Ministry Scientific Research Pool for service at the Royal Aircraft Establishment, South Farnborough, Hants-The Chief Superintendent (June 19).

A head of the Department of Electrical Engineering in the Rutherford Technical College, Newcastle-uponTyne-The Director of Education, City Education Office, Northumberland Road, Newcastle-upon-Tyne, 2 (June 20).

A teacher of mathematics and a teacher of technical drawing in the Wandsworth Technical Institute, London, S.W.18-The Secretary (June 22).

A lecturer and an assistant lecturer in engineering (civil or municipal) in University College, London, W.C.1-The Secretary (June 25).

An assistant (Grade II) in the Admiralty Scientific and Technical Pools (physics or electrical engineering) -The Secretary of the Admiralty (C.E. Branch), Whitehall, London, S.W.1 (June 26).

A scientific officer for research on internal combustion engines at the Royal Aircraft Establishment, South Farnborough, Hants (Royal Aircraft Scientific Research Pool) - The Chief Superintendent (June 26).

An assistant lecturer in physics in University College, Southampton-The Registrar (June 30).

A chemist in a War Department at WoolwichThe Under-Secretary of State (C. 5), The War Office, London, S.W.1 (June 30).

A technical officer in the Meteorological OfficeThe Secretary (S. 2. e.), Air Ministry, Adastral House, Kingsway, London, W.C.2 (July 3).

A chief mechanical engineer at the Royal Naval Cordite Factory, Halton Heath, Dorset-The Secretary of the Admiralty (C.E. Branch), London, S.W.1.

An assistant lecturer in geology and geography in King's College, Strand, London, W.C.2-The Secretary. 